\title{
PERANCANGAN SISTEM TELEMETRI DETEKSI BENCANA BANJIR BERBASIS WEB SERVER DAN SMS GATEWAY
}

\author{
Faisal Hadi, S.T., M.T. ${ }^{1}$, Reza Satria Rinaldi, S.T., M.Eng ${ }^{1}$ Rahmat Supartian ${ }^{1}$, \\ ${ }^{1}$ Program Studi Teknik Elektro, Fakultas Teknik, Universitas Bengkulu \\ faisalhadi@unib.ac.id
}

\begin{abstract}
Indonesia is one of the areas prone to disasters, especially floods. The impact of flooding can be reduced if the community is better prepared to face the coming flood. Therefore we need an early flood detection tool that can give a signal to the community through early warning so that the community can be more alert in facing flood disastersThe results of this design make two systems, the main control system and the receiving system. The main control system consists of an ultrasonic sensor, SIM800L module and NodeMCU Wi-Fi module. The receiving system consists of a SIM800L module and a siren. The results showed that the ultrasonic sensor used has a good level of accuracy with an error value $<1 \%$. The results of SMS testing have a delay until the SMS to the recipient is around 5-10 seconds. The test results also show that $4 \mathrm{G}$ network technology has $100 \%$ delivery accuracy and 3-4 seconds delivery delay per data. The final result shows thatthe system is able to work as desired and is able to be well connected to the web server.
\end{abstract}

Keyword:Flood Disasters, SIM800L, Ultrasonic sensor, Web Servers, SMS

\begin{abstract}
Abstrak
Indonesia adalah salah satu daerah yang rawan akan bencana, terutama bencana banjir. Dampak dari banjir dapat dikurangi jika masyarakat lebih siap dalam menghadapi datangnya banjir tersebut. Oleh karena itu dibutuhkan alat pendeteksi dini banjir yang dapat memberikan isyarat kepada masyarakat melalui peringatan dini sehingga masyarakat lebih bisa siaga dalam menghadapi bencana banjir. Hasil dari perancangan ini membuat dua sistem yaitu sistem kendali utama dan sistem penerima. Sistem kendali utama terdiri dari sensor ultrasonik, modul SIM800L dan modul Wi-Fi NodeMCU. Sistem penerima terdiri dari modul SIM800L dan sirine. Dari hasil penelitian menunjukkan bahwa sensor ultrasonik yang digunakan memiliki tingkat akurasi yang baik
\end{abstract}

dengan nilai error $<1 \%$. Hasil pengujian SMS memiliki delay sampai sms ke penerima sekitar 5 10 detik. Hasil pengujian juga menunjukkan bahwa teknologi jaringan 4G memiliki akurasi pengiriman $100 \%$ dan delay pengiriman 3-4 detik per data. Hasil akhir menunjukkan bahwa sistem mampu bekerja sesuai dengan keinginan dan mampu dengan baik terkoneksi dengan web server.

Kata Kunci: Bencana Banjir, SIM800L, sensor Ultrasonik, Web Server, SMS

\section{Latar Belakang}

Indonesia adalah salah satu daerah yang rawan akan bencana, terutama bencana banjir. Hal ini disebabkan karena wilayah Indonesia terletak di daerah iklim tropis dengan dua musim yaitu panas dan hujan dengan ciri-ciri adanya perubahan cuaca, suhu dan arah angin yang cukup ekstrim. Kondisi iklim tropis yang ekstrim ini bila digabungkan dengan kondisi topografi permukaan dan batuan yang relatif beragam, ditambah aktivitas manusia terhadap lingkungan yang cenderung semakin destruktif dapat menimbulkan beberapa akibat buruk bagi manusia, antara lain banjir.

Kejadian bencana alam yang terjadi di Indonesia sejak tahun 2010 sampai 2019, tiga kategori bencana yang memiliki tingkat kejadian yang tinggi di Indonesia yaitu puting beliung, tanah longsor dan banjir. Data BNBP hingga akhir bulan September 2019, mencatat jumlah kejadian banjir di Indonesia telah mencapai 549 kejadian, tanah longsor 550 kejadian, dan puting beliung 725 kejadian. Namun dari ketiga kategori bencana yang sering terjadi di Indonesia, bencana banjir yang paling banyak menimbulkan jumlah korban yang meninggal atau hilang, sekitar 326 orang [1].

Dampak dari banjir dapat dikurangi jika masyarakat lebih siap dalam menghadapi datangnya banjir tersebut. Salah satu caranya adalah dengan memberikan informasi dan peringatan dini, sehingga mampu mengurangi jumlah korban akibat kurang persiapan masyarakat dalam menghadapi bencana banjir.

Penelitian terdahulu mengenai teknologi deteksi banjir telah banyak dilakukan oleh peneliti. Salah 
satunya penelitian yang dilakukan oleh Robby Syahaputra yaitu perancangan sistem peringatan dini banjir jarak jauh berdasarkan ketinggian airmenggunakan sensor ultrasonik.

Pada penelitian yang dilakukan oleh Roby Syahputrapengiriman data yang dilakukan menggunakan sistem penangkapan sinyal pada sensor sebagai pemancar (transmitter) dan akan diterima (receiver) sebagai sistem pusat data. Namun, sistemnya belum secara real-time untuk memonitoring keadaan air secara online dan masih menggunakan gelombang radio sebagai pengiriman sinyanya [2].Berdasarkan masalah tersebut maka diusulkan sebuah judul penelitian "Perancangan Sistem Telemetri Deteksi Bencana Banjir Berbasis Web Server Dan Sms Gateway".

\section{Landasar Teori}

Sistemperingatan dini adalah penyediaan informasiyang tepat dan efektif melalui lembagaterpercaya yang memungkinkan seseorangdalam kondisi bahaya untuk mengambil tindakan menghindari atau mengurangi risiko.Sistem peringatan dini tidak harus bersifat topdown,tetapi bisa juga bersifat bottom-upmelalui keterlibatan masyarakat [3].

Internet of Things adalah sebuah teknologi yang memungkinkan kita untuk menghubungkan mesin, peralatan, dan benda fisik lainnya dengan sensor jaringan dan aktuator untuk memperoleh data dan mengelola kinerjanya sendiri. Internet of Things mampu memperluas jangkauan teknologi informasi. Banyak sekali kemungkinan yang timbul dari kemampuan untuk memantau dan suatu things secara fisik berbasis elektronik yang menginspirasi majunya gelombang inovasi dan antusiasme [4].

Web adalah kumpulan halaman-halaman yang digunakan untuk menampilkan informasi teks, gambar diam atau gerak, animasi, suara, dan atau gabungan dari semuanya itu baik yang bersifat statis maupun dinamis yang membentuk satu rangkaian bangunan yang saling terkait dimana masing-masing dihubungkan dengan jaringan-jaringan halaman (hyperlink). Unsur-unsur web yaitu, nama domain, web hosting, scripts program, desain website dan pemeliharaan website [5].

Gelombang ultrasonik merupakan gelombang yang memiliki batasan hingga jangkauan frekuensi diatas batas pendengaran manusia, yakni lebih besar dari ukuran $20 \mathrm{kHz}$. Sehingga pada saat pemantulan yang terjadi mengenai suatu objek pemantulan, maka ada sebagian yang dipantulkan, sebagian di teruskan, dan sebagian lagi diserap [6].

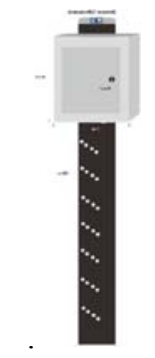

(a)

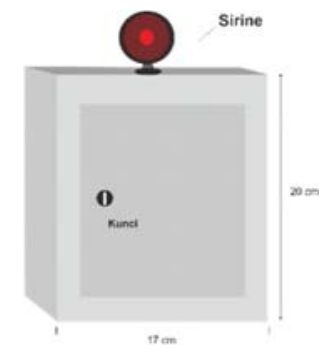

(b)
Gambar 1. Desain Alat (a) Bagian Sistem Kendali Utama (b) Bagian Sistem Penerima

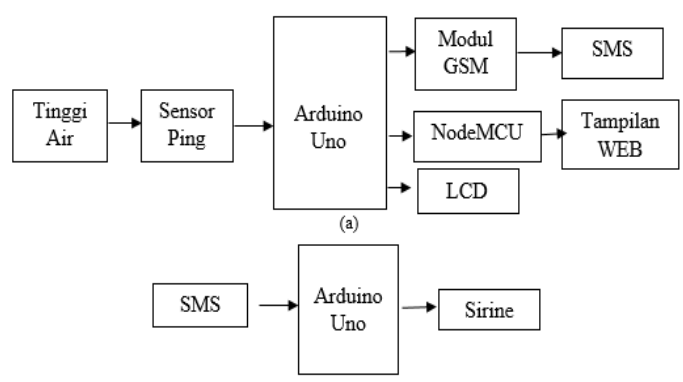

(b)

Gambar 2. Diagarm Blok Sistem

Pengiriman SMS dari dan ke PC perlu dilakukan terlebih dahulu koneksi ke SMSC. Koneksi PC ke SMSC adalah dengan menggunakan terminal berupa GSM modem ataupun ponsel yang terhubung dengan PC. Dengan menggunakan ponsel, SMS yang mengalir dari atau ke SMSC harus berbentuk PDU (Protocol Data Unit). PDU berisi bilangan - bilangan heksadesimal yang mencerminkan 10 bahasa I/O (kode). PDU sendiri terdiri atas beberapa bagian yang berbeda antara mengirim dan menerima SMS dari SMSC. Format data PDU ini dikirimkan ke PC dalam bentuk teks (string) yang menunjukkan nilai heksadesimalnya. Jadi saat ponsel mengirim data heksadesimal $\mathrm{F}(\mathrm{OFH})$, maka yang diterima oleh PC adalah teks F [7].

\section{Metode Penelitian}

\section{A. Perancangan Sistem}

Perancangan sistem yang terdiri atas perancangan hardware dan implementasi software. Perancangan hardware bertujuan untuk merangkai seluruh komponen sistem hingga terbentuk rancangan pada Gambar 1.Perancangan software bertujuan sebagai sistem kendalinya pada mikrokontroler arduino yang akan mengolah data dari sensor sehingga alat dapat berfungsi sesuai dengan prinsip kerja yang diharapkan.

Gambar 1 menjelaskan bahwa sistem akan menjadi 2 bagian yaitu bagian sistem kendali utama dan bagian sistem penerima. 


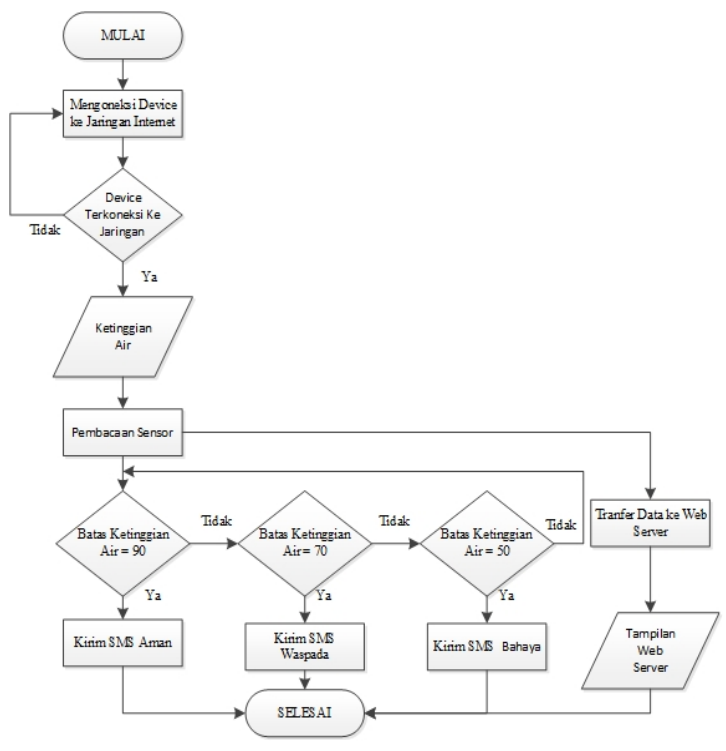

Gambar 3. Flowchart Sistem Kendali Utama

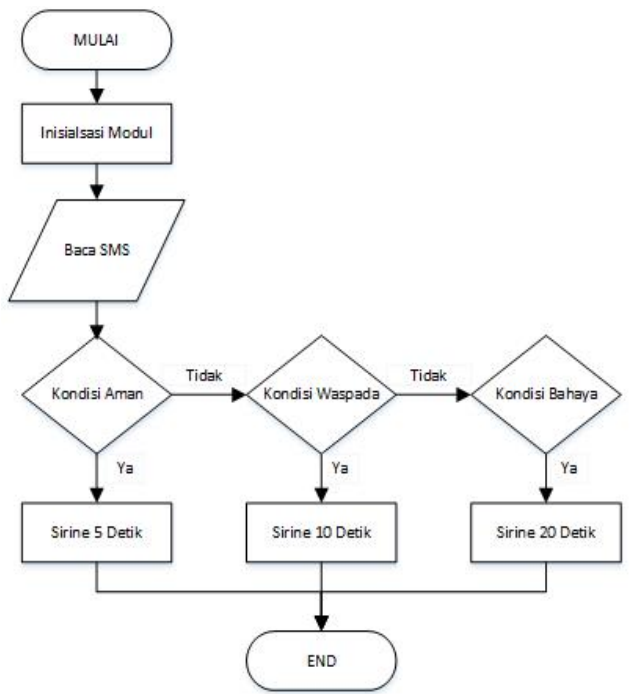

Gambar 4. Flowchart Sistem Penerima

Gambar 2 merupakan blok diagram dari sistem dari sistem kendali utama dan sistem penerima.Pada saat sistem dihidupkan, Arduino akan mendeteksi ketinggian air menggunakan sensor ultrasonik, setelah didapat berapa ketinggian air, maka ketinggian air akan ditampilkan pada LCD dan dapat dimonitoring melalui web yang telah terhubung oleh sistem. Dan sistem juga akan mengirimkan SMS ke no yang telah terdaftar oleh sistem dan mengirimkan sms ke sistem penerima untuk menghidupkan sirine.

Berdasarkan Gambar 3Flowchart sistem kendali utama dan gambar 4 Flowchart sistem penerima dapat dijelaskan bahwa :

1. Tahap pertama ketika sistem telah diaktifkan, device secara otomatis mencoba menghubungkan ke jaringan internet, pada tahap ini device dikoneksikan ke jaringan internet melalui modul NodeMCU. Apabila device belum terhubung dengan jaringan internet maka proses ini akan terus berlanjut hingga device tersambung ke internet. Setelah sistem terkoneksi dengan jaringan internet, secara berkelanjutan sistem mengirim data pada webserver.

2. Tahap selanjutnya adalah sensor mendeteksi batas ketinggian air. Hasil pembacaan sensor akan diterima oleh mikrokontroler yang kemudian akan diolah dan dikirim ke webserver sebagai pemonitoring batas ketinggian air.

3. Tahap menampilkan data pada webbrowser. Pada tahap ini data dapat ditampilkan melalui webbrowser dengan mengakses halaman webserver.

4. Tahap kondisi ketinggian air. Pada tahap ini kondisi air dibagi menjadi tiga bagian, yaitu kondisi aman dengan batas ketinggian air adalah $90 \mathrm{~cm}$, kondisi waspada dengan batas ketinggian air adalah $70 \mathrm{~cm}$ dan kondisi bahaya dengan batas ketinggian air adalah 50 $\mathrm{cm}$.

5. Tahapan pengiriman sms. Pada tahap ini sms ini yaitu sistem akan melakukan sms sesuai dengan tiga kondisi batas ketinggian air, yaitu pada saat air mencapai kondisi yang telah ditentukan maka sistem akan mengirimkan sms sesuai kondisi yang didapat ke nomer handphone yang telah ditentukan dan mengirim sms ke sistem penerima untuk menghidupkan sirinenya.

\section{Hasil dan Pembahasan}

\section{A. Pengujian Sensor Ultrasonik Ping Paralax}

Pada pengujian ini dilakukan menggunakan pipa dengan diameter $10 \mathrm{~cm}$ dan tinggi pipa $100 \mathrm{~cm}$. Sensor diletakkan tepat ditengah pipa sesuai dengan lebar pita sensor ultrasonik. Pengukuran disini dilakukan untuk mengukur lasngsung ke permukaan air sehingga data yang didapat adalah data ketinggian jarak air dengan panjang pipa.

Pada tahap ini pipa berangsur-angsur diisi air dan diukur ketinggiannya sesuai data yang dinginkan. Pada pengukuran ini terdapat 10 variasi data yang didapat yaitu pada data terukur $5 \mathrm{~cm}, 10 \mathrm{~cm}, 20 \mathrm{~cm}, 30 \mathrm{~cm}, 40$ $\mathrm{cm}, 50 \mathrm{~cm}, 60 \mathrm{~cm}, 70 \mathrm{~cm}, 80 \mathrm{~cm}$ dan $90 \mathrm{~cm}$ dengan perulangan 10 kali perulangan per data. Dari hasil pengujian maka dapat dilihat hubungan dari waktu pantul rata-rata dengan jarakyang terukur sensor ultrasonik ping paralax seperti grafik pada Gambar 5. 


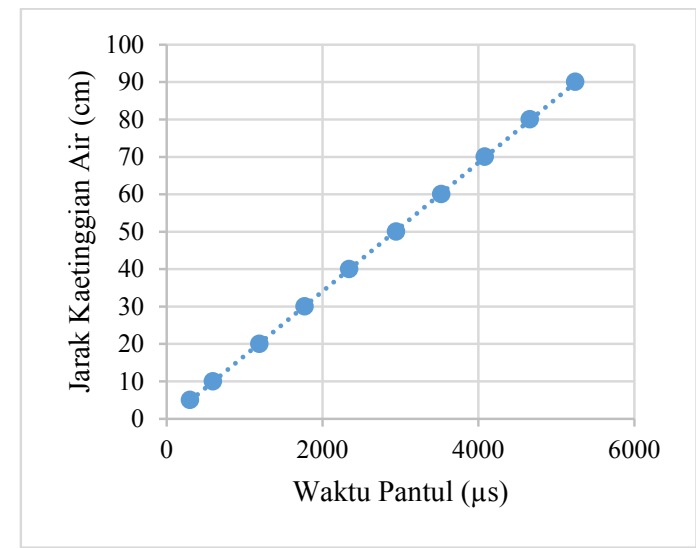

Gambar 5. Grafik Permbandingan Antara Jarak Ketinggian Air dan Waktu Pantul

Tabel 1. Data Hasil Perhitungan Jarak Dan Persentase Error Sensor Ultrasonik Ping Paralax

\begin{tabular}{ccccc}
\hline No & $\begin{array}{c}\text { Jarak } \\
\text { Terukur } \\
(\mathrm{cm})\end{array}$ & $\begin{array}{c}\text { Waktu Pantul } \\
\text { Rata-Rata } \\
(\boldsymbol{\mu s})\end{array}$ & $\begin{array}{c}\text { Jarak } \\
\text { Hitung } \\
(\mathrm{cm})\end{array}$ & $\begin{array}{c}\text { Error } \\
(\%)\end{array}$ \\
\hline 1 & 5 & 299,8 & 5,09 & 1,8 \\
2 & 10 & 593,4 & 10,08 & 0,8 \\
3 & 20 & 1188,6 & 20,20 & 1 \\
4 & 30 & 1770,2 & 30,09 & 0,3 \\
5 & 40 & 2341,1 & 39,79 & 0,52 \\
6 & 50 & 2943,5 & 50,03 & 0,06 \\
7 & 60 & 3523 & 59,89 & 0,18 \\
8 & 70 & 4079,9 & 69,35 & 0,92 \\
9 & 80 & 4659,4 & 79,20 & 1 \\
10 & 90 & 5242,4 & 89,12 & 0,97 \\
& & Rata-rata error & & $0,75 \%$ \\
\hline
\end{tabular}

Bedasarkan Gambar 5 perbandingan antara pengukuran jarak ketinggian air $(\mathrm{cm})$ dengan waktul pantul ( $\mu \mathrm{s})$ yaitu berbanding lurus atau linier.Dari hasil perhitungan nilai jarak sensor (s) dapat dilakukan perhitungan nilai error yang terjadi. Hasil perhitungan jarak sensor (s) dan persentase error pada pembacaan sensor ultrasonik ping paralax dapat dilihat pada Tabel 1.

Tabel 1 menunjukkan bahwapersentase error pada sensor ultrasonik ping paralax ini adalah sebesar $0,75 \%$ yang mana sesuai dengan datasheet sensor ultrasonik ping paralax yang meyatakan akurasi dari sensor tersebut bisa mencapai $3 \mathrm{~mm}$. Waktu pantul ini yaitu merupakan delay waktu yang terbaca dari sensor sampai menyentuh permukaan air dan memantulkan kembali ke sensor, semakin cepat kenaikan air maka waktu pantul yang didapat akan semakin cepat.

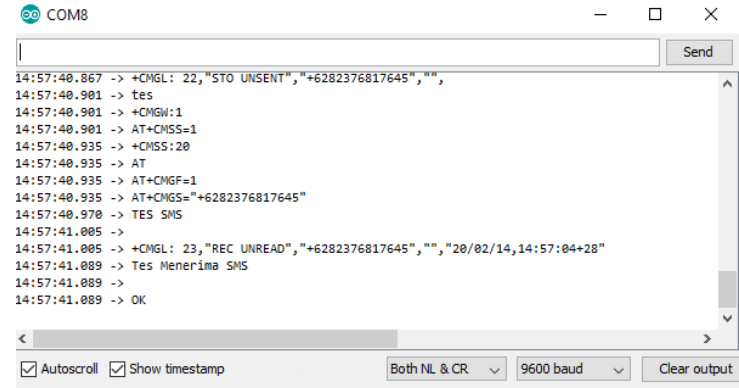

Gambar 6. Hasil Pengujian AT-Command Modul SIM800L

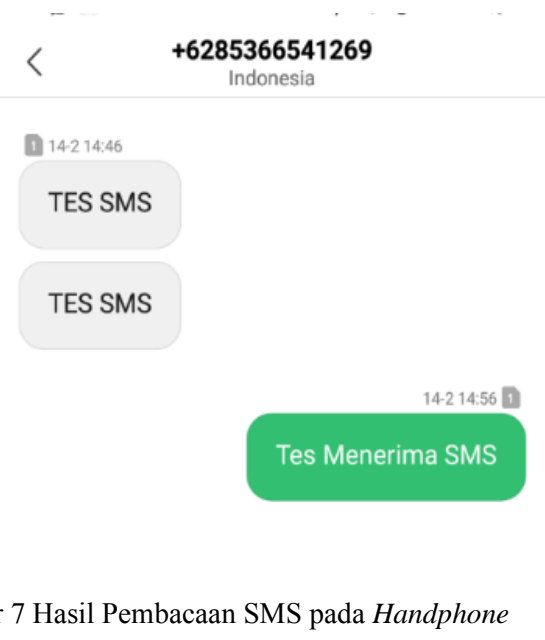

\section{B. Pengujian Modul SMS SIM800L}

Dalam pengujian ini modul SIM800L menggunakan power supply dengan modul stepdown, karna modul SIM800L bekerja pada tegangan 3,7 volt - 4,2 volt [8] dan stepdown diatur pada tengangan 4 volt. Lama modul SIM800L dalam mendapatkan sinyal \pm 5 detik dengan tanda led indikator pada modul SIM800L akan berkedip lambat. Setelah tahap pengujian sinyal maka dapat dilakukan pengujian ATCommand untuk melihat apakah modul SIM800L dapat bekerja dengan baik. Hasil pengujian modul SMS SIM800L dapat dilihat pada Gambar 6.

Kode-kode pada kotak merah dan hijau pada Gambar 6 merupakan kode-kode perintah ATCommand. Kode program pada kotak merah adalah kode program yang digunakan untuk meng-SMS no handphone. AT merupakan kode AT-Command yang berfungsi untuk mengecek apakah modul SIM800L aktif dan mendapatkan sinyal atau tidak dan merupakan proses TES SMS ke no handphone. Kode program pada kotak hijau digunakan untuk melihat SMS masuk yang terkirim ke modul SIM800L. Hasil pembacaan SMS pada handphone dapat dilihat pada Gambar 7. 


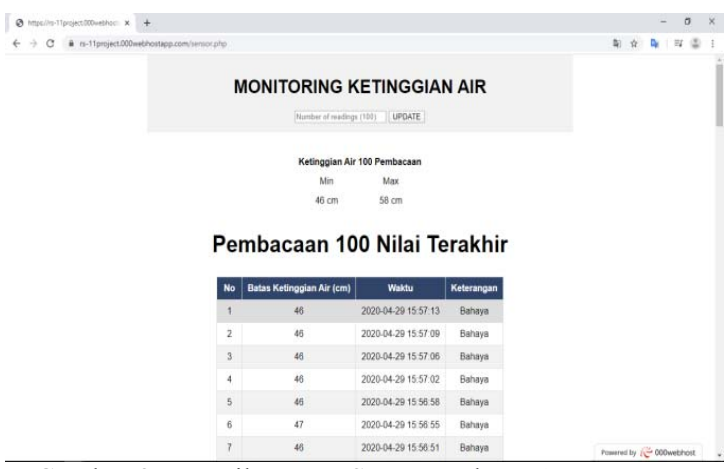

Gambar 8. Tampilan Data Sensor Pada Web Monitoring

Tabel 2. Data Pengukuran Arus pada Sistem Kendali Utama

\begin{tabular}{clcc}
\hline No & Keterangan & Nilai Arus (A) & $\begin{array}{c}\text { Daya } \\
\text { (Watt) }\end{array}$ \\
\hline 1 & Standby & 0,16 & 1,44 \\
2 & Mengirim SMS & 0,20 & 1,8 \\
\hline
\end{tabular}

Gambar 7 dapat dilihat bahwa terdapat hasil pengiriman SMS dari modul SIM800L dan SMS Handphone mengirim SMS ke modul SIM800L. Modul SIM800L memiliki waktu dari mulai pengiriman SMS sampai ke handphone sekitar \pm 5 detik. Berdasarkan hasil pengujian dapat disimpulkan bahwa modul SIM800L dapat berjalan dengan baik dan siap digunakan.

\section{Pengukuran Daya Yang Terpakai}

Pengukuran daya berguna untuk mengetahui konsumsi daya yang dipakai oleh sistem yang dibuat sehingga apabila sistem akan diterapkan pada lapangan nantinya, bisa mempertimbangkan power supply yang akan digunakan pada saat dilapangan nantinya. Untuk pengujian ini power supply yang digunakan menggunakan adaptor 9 Volt dengan batas arus sebesar 1 Ampere untuk sistem kendali utama yang supply Arduino Uno dan modul SIM800L. Selanjutnya pada sistem penerima pada pengujian ini menggunakan adaptor 12 Volt dengan batas arus sebesar 2 Ampere untuk supply Arduino uno, modul SIM800L dan Sirine.

\section{Pengukuran pada Sistem Kendali Utama}

Hasil pengukuran arus yang didapat yaitu pada saat standby sebesar 0,16 A dan pada saat sistem melakukan pengiriman SMS arus yang terukur sebesar 0,20 A tetapi terjadi hanya beberapa detik saja saat terjadi pengiriman SMS. Hasil pengukuran arus dan perhitungan daya pada sistem kendali utama dapat dilihat pada Tabel 2 .

Dari Tabel 2 nilai arus dari sistem ini cukup kecil
Tabel 3. Data Pengukuran Arus pada Sistem Penerima

\begin{tabular}{cccc}
\hline No & Keterangan & Nilai Arus (A) & Daya (Watt) \\
\hline 1 & Standby & 0,07 & 0,84 \\
2 & Mengirim SMS & 0,86 & 10,32 \\
\hline
\end{tabular}

yaitu sebesar 0,16 A untuk konsumsi dari seluruh komponen yang digunakan dan daya yang terpakai juga kecil sekitar 1,44 Watt. Dan pada saat mengirimkan SMS kenaikkan arus pun kecil, hanya sebesar 0,4 A dan cuma berlangsung beberapa detik saja.

\section{Pengukuran Pada Sistem Penerima}

Hasil pengukuran arus yang didapat yaitu pada saat standby sebesar 0,07 A dan pada saat sistem mendapatkan SMS dan menghidupkan sirine arus yang terukur sebesar 0,86 A. Hasil pengukuran arus dan perhitungan daya pada sistem penerima dapat dilihat pada Tabel 3.

Dari data hasil pengukuran arus dan perhitungan daya, nilai arus dari sistem ini cukup kecil yaitu sebesar 0,07 A untuk konsumsi dari seluruh komponen yang digunakan dan daya yang terpakai juga kecil sekitar 1,92 Watt. Dan pada saat menerima SMS serta menghidupkan sirine kenaikkan arus pun besar, yaitu sebesar 0,79 A sehingga arus menjadi 0,86 A.

\section{Web Monitoring}

Web monitoring merupakan web yang digunakan untuk melihat hasil pembacaan sensor secara real time. Data yang ditampilkan pada web monitoring merupakan data yang diambil dari database sensor. Data dari web server kemudian ditampilkan dalam bentuk tabel pada web monitoring. Tampilan data pada web monitoring menampilkan 100 data terakhir dari pembacaan sensor. Tampilan web monitoring dapat dilihat pada halaman webhttps://rs-11 project.000webhostapp.com/sensor.phpdan bentuk tampilan pada web seperti pada Gambar 8.Dari Gambar 8 dapat dilihat tampilan web monitoring menampilkan data pengukuran dalam bentuk tabel dan memberi tahu nilai minimal serta maksimal dari 100 data terakhir pembacaan sensor.

Pengujian selanjutnya untuk melihat teknologi jaringan apa yang cocok untuk sistem. Pengujian dilakukan menggunakan tiga jenis teknologi jaringan yaitu 2G, 3G dan 4G. Langkah awal dari pengujian ini adalah Test Ping Google untuk menguji seberapa cepat teknologi jaringan yang digunakan dalam mengirim dan menerima data dari Google. Hasil pnegujian Test Ping Google dapat dilihat pada Gambar 9. 


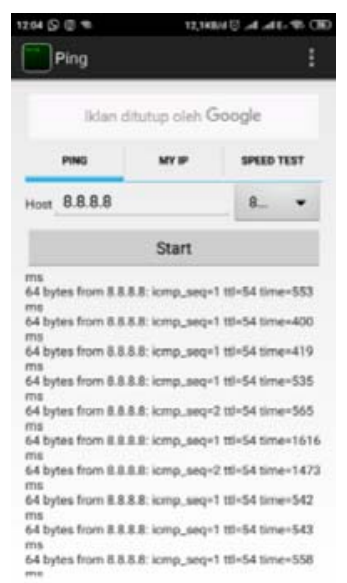

(a)

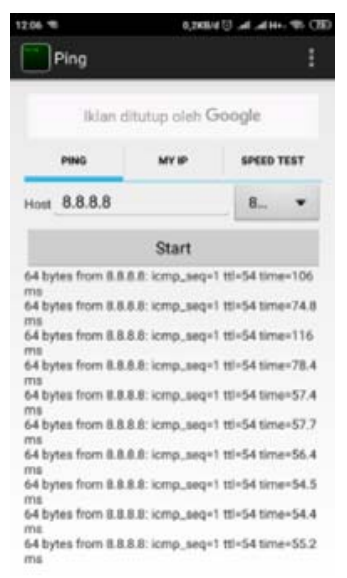

(b)

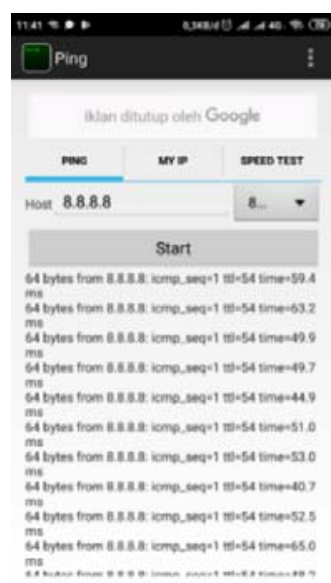

(c)

Gambar 9. Hasil Test Ping Google (a) Jaringan 2G, (b) Jaringan 3G, (c) Jaringan 4G

Tabel 5. Data Pengujian Koneksi Jaringan Sistem Ke Web Server

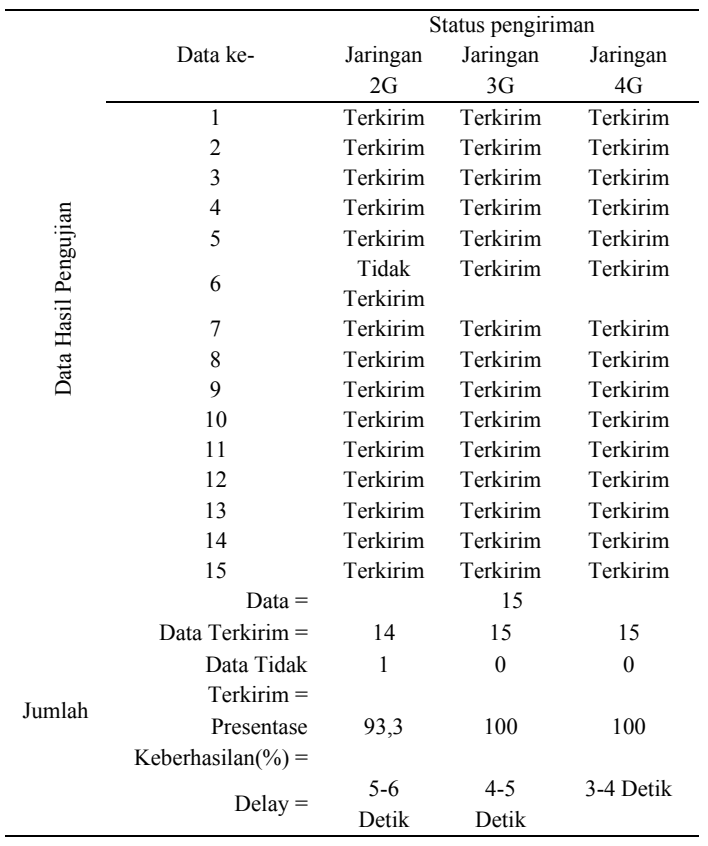

Berdasarkan Gambar 9 dapat dilihat bahwa kecepatan akses pada jaringan $2 \mathrm{G}$ terlihat lambat dimana kecepatan rata-rata 720 millisecond. Pada pengujian jaringan $3 \mathrm{G}$ dengan pengiriman dan penerima data yang sama membutuhkan waktu sekitar 71 millisecond dan pada jaringan 4G membutuhkan waktu sekitar 52 millisecond.

Tahap selanjutnya yaitu pengujian koneksi jaringan $2 \mathrm{G}, 3 \mathrm{G}$ dan $4 \mathrm{G}$ untuk pengiriman data sensor ke database web server. Pada sistem diatur minimal waktu pengiriman yaitu 3 detik sekali. Hasil pengujian pengiriman dapat dilihat pada serial monitor Arduino dan web monitoring sistem. Hasil pengujian dilihat dari serial monitor Arduino seperti pada Tabel 5.

Tabel 5 menunjukkan dari jumlah data sebanyak 15 sempel pengiriman data, dapat dilihat bahwa jaringan yang memiliki tingkat keberhasilan mencapai $100 \%$ pada jaringan $3 \mathrm{G}$ dan jaringan $4 \mathrm{G}$. Pada jaringan 2G tingkat keberhasilan pengiriman juga termasuk tinggi walaupun terdapat data yang tidak terkirim ke web server dengan tingkat keberhasilan pengiriman data yaitu 93,3\% ini dikarenakan jaringan $2 \mathrm{G}$ memiliki PING Google yang lemah sehingga pengiriman menjadi lambat.

Berdasarkan beberapa tahap pengujian yang telah dilakukan dapat disimpulkan bahwa kecepatan pengiriman data web monitoring tergantung dari kecepatan jaringan yang digunakan. Gambar 9 menunjukkan bahwa PING Google yang baik untuk pengiriman data dari sistem ke web server yaitu dibawah 200ms dan jaringan yang mampu mencapai kecepatan ini adalah jaringan $3 \mathrm{G}$ dan $4 \mathrm{G}$ serta dua jaringan ini memiliki keberhasilan mencapai $100 \%$ dalam pengririman data yang dilakukan.

\section{E. Pengujian Sistem secara Keseluruhan}

Pengujian sistem secara keseluruhan dilakukan untuk melihat respon sistem dalam menanggapi kondisi perubahan dari jarak yang terukur oleh sensor, pengiriman dan penerimaan SMS dari modul SMS SIM800L, Modul Wi-Fi NodeMCU sebagai pengirim data ke web server dan pengujian sirine peringatan. Sistem keseluruhan dibagi menjadi 2 yaitu sistem kendali utama dan sistem penerima.

Pada sistem kendali utama terdapat sensor ultrasonik yang dipasang di atas pipa setinggi $100 \mathrm{~cm}$ yang berfungsi sebagai pembaca jarak sensor ke air. Modul SMS SIM800L akanstandby sesuai dengan aturan yang dibuat oleh sistem. Modul Wi-Fi NodeMCU akan selalu mengirimkan data sensor ke web server. 
Tabel 6 Data hasil pengujian alat keseluruhan

\begin{tabular}{ccccc}
\hline Jarak & \multicolumn{2}{c}{ Sistem Kendali Utama } & \multicolumn{2}{c}{ Sistem Penerima } \\
$\begin{array}{c}\text { Sensor } \\
\text { ke Air }\end{array}$ & SMS & Web & SMS & Sirine \\
\hline $100 \mathrm{~cm}$ & Standby & Mengirim & Standby & Mati \\
$90 \mathrm{~cm}$ & Mengirim & Mengirim & Menerima & Hidup \\
$70 \mathrm{~cm}$ & Mengirim & Mengirim & Menerima & Hidup \\
$50 \mathrm{~cm}$ & Mengirim & Mengirim & Menerima & Hidup \\
\hline
\end{tabular}

Pengujian dilakukan dengan menambahkan air sehingga jarak sensor ke air akan berkurang sesuai dengan kenaikkan air dalam pipa. Apabila ketinggian air mencapai tinggi sesuai dengan program sistem, maka modul SMS SIM800L akan mengirimkan SMS ke no handphone yang telah ditetapkan sistem dan mengirim juga sms ke sistem penerima untuk menghidupkan sirine sesuai keadaan ketinggian air.Modul SIM800L memiliki waktu dari mulai pengiriman SMS sampai ke handphone sekitar \pm 5 detik

Pada pengujian ini terdapat 3 kondisi yang diterapkan sistem yaitu kedaan "Aman", "Waspada", dan "Bahaya". Aman yaitu apabila ketinggian air mencapai jarak $90 \mathrm{~cm}$ dari sensor lalu sistem akan mengirimkan SMS ke no handphone dan ke sistem penerima. Waspada yaitu apabila ketinggian mencapai jarak $70 \mathrm{~cm}$ dari sensor sistem akan mengirimkan SMS ke no handphone dan ke sistem penerima. Bahaya yaitu apabila ketinggian mencapai jarak $50 \mathrm{~cm}$ dari sensor sistem akan mengirimkan SMS ke no handphone dan ke sistem penerima.

Pada sistem penerima sistem akan selalu standby dan apabila modul SMS SIM800L menerima SMS dari sistem kendali utama maka sistem penerima akan menghidupkan sirine sesuai kondisi yang dikirim oleh sistem kendali utama. Pada saat sistem menerima SMS kondisi "Aman" maka sistem akan menghidupkan sirine selama 5 detik. Begitupun dengan kondisi "Waspada" dan "Bahaya" akan menghidupkan sirine selama 10 detik dan 20 detik.

Berdasarkan beberapa pengujian tersebut maka didapat data hasil pengujian alat keseluruhan seperti pada Tabel 6.Tabel 6 memperlihatkan bahwa sistem mampu menjalankan tugas sesuai dengan diagram alir yang telah dirancang, dimana pada jarak sensor mencapai $90 \mathrm{~cm}$ maka sistem kendali utama akan mengirim sms dan sistem penerima menerima sms serta menghidupkan sirine sesuai waktunya, begitupun dengan jarak $70 \mathrm{~cm}$ dan $50 \mathrm{~cm}$ sistem bisa berjalan sesuai dengan yang diinginkan. Web server juga selalu menampilkan jarak yang terkirim oleh sistem ke web server dengan baik dan delay waktu real time dari sistem ini yaitu pengiriman per 3 detik. Maka dari percobaan yang dilakukan dapat disumpulkan bahwa sistem secara keseluruhan dapat berjalan dengan baik sesuai dengan yang diingikan.

\section{Kesimpulan}

1. Sistem pendeteksi banjir yang dirancang terdiri dari dua sistem yaitu sistem kendali utama sebagai pendeteksi ketinggian level air dan monitoring web. Kemudian sistem penerima sebagai peringatan akan adanya banjir.

2. Sensor Ultrasonik Ping Paralax yang digunakan memiliki akurasi yang baik dengan tingkat ratarata error sebesar $0,75 \%$.

3. Sistem telemetri peringatan dini menggunakan SMS Gateway memiliki delay sekali pengiriman ke no handphone sekitar sekitar \pm 5 detik dan sampai ke sistem penerima memiliki delay sekitar \pm 10 detik, ini dikarenakan sistem kendali utama mengirim SMS terlebih dahulu ke no handphone dilanjukan ke sistem terima.

4. Penggunakan teknologi jaringan pada Wi-Fi yang digunakan untuk menghubungkan sistem dengan web server mempengaruhi fungsi web server dalam meyimpan dan memberikan informasi data. Penggunaan teknologi jaringan yang mampu memiliki kecepatan ping google dibawah $200 \mathrm{~ms}$ merupakan pilihan terbaik yang bisa digunakan yaitu teknologi jaringan 4G dengan akurasi pengiriman $100 \%$ dan delay pengiriman 3-4 detik per data.

\section{Referensi}

[1]. "Data Informasi Bencana Indonesia". http://dibi.bnpb.go.id. Diakses pada 21 Oktober 2019 Pukul 15.03 WIB

[2] Syaputra, Robby. 2015. Perancangan Sistem Peringatan Dini Banjir Jarak Jauh Berdasarkan Ketinggian Air Menggunakan Sensor Ultrasonik. Skripsi, Program Studi Teknik Elektro, Fakultas Teknik, Universitas Bengkulu, Bengkulu.

[3] Sariffuddin. (2015). Peluang PengembanganSmart City Untuk Mewujutkan KotaTangguh di Kota Semarang. Jurnal Teknik,36(1), 32-38

[4] Miller, Michael. 2015. The Internet of Things: How Smart TVs, Smart Cars, Smart Homes, and Smart Cities are Changing The World. Indianapolis: Pearson Education.

[5] Winarno, Edi, 2014. PemrogramanWebBerbasisHtml 5, Php, \&Javascript. Edisi kelima Jilid 2. Penerbit Elex Media Komputindo, Jakarta.

[6] Sukarno. 2010. Ultrasonik Generator Dengan Frekuensi Maksimum $100 \mathrm{kHz}$ Dan Daya 100 Watt Berbasis Mikrokontroler AVR AT TINY 2313. Tesis. Fakultas Matematika Dan Ilmu 
Jurnal Amplifier Mei 2020 Vol 10 No 1 P-ISSN 2089-2020 dan E-ISSN 2622-2000

Pengetahuan Alam Magister Fisika. Universitas Indonesia.

[7] Prasetyo, Indra. 2011. Sistem Laporan Perkembangan Belajar Siswa Berbasis Web Terintegrasi dengan Mobile Technology dengan SMS Gateway (Studi Kasus : Mumtaza Islamic
School). Skripsi, Progam Studi Sistem Informasi, Fakultas Sains dan Teknologi, Universitas Islam Negeri Hidayatullah Jakarta. Jakarta.

[8].2013.SIM800L_Hardware_Design_V1.00.DatasheetSIM8 $00 \mathrm{~L}$. 